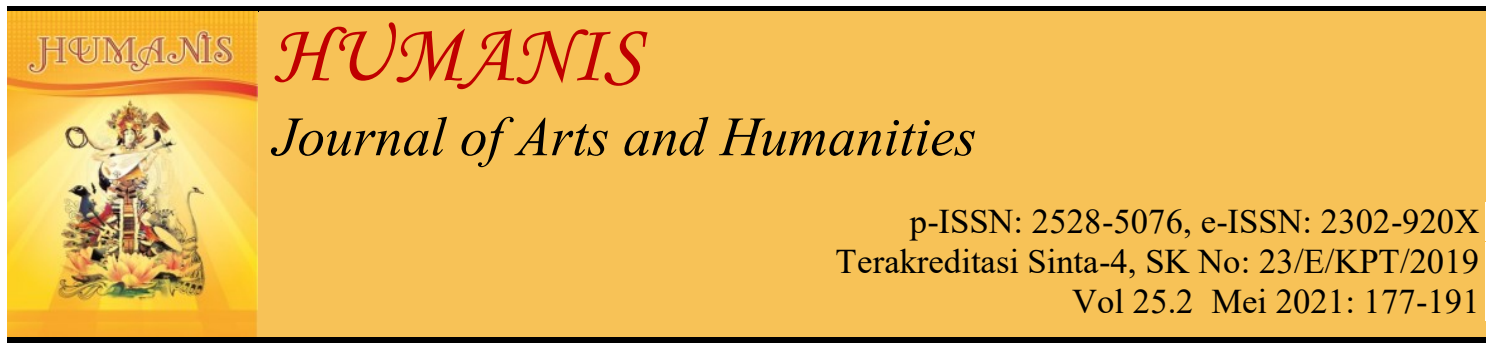

\title{
Estetika Sebagai Motivasi Pelisanan dalam Mabebasan di Bali
}

\author{
Anak Agung Gede Bawa, I Nyoman Sukartha \\ Universitas Udayana, Denpasar, Bali, Indonesia \\ Correspondence e-mail. aagedebawa@gmail.com, inyomansukartha@yahoo.co.id
}

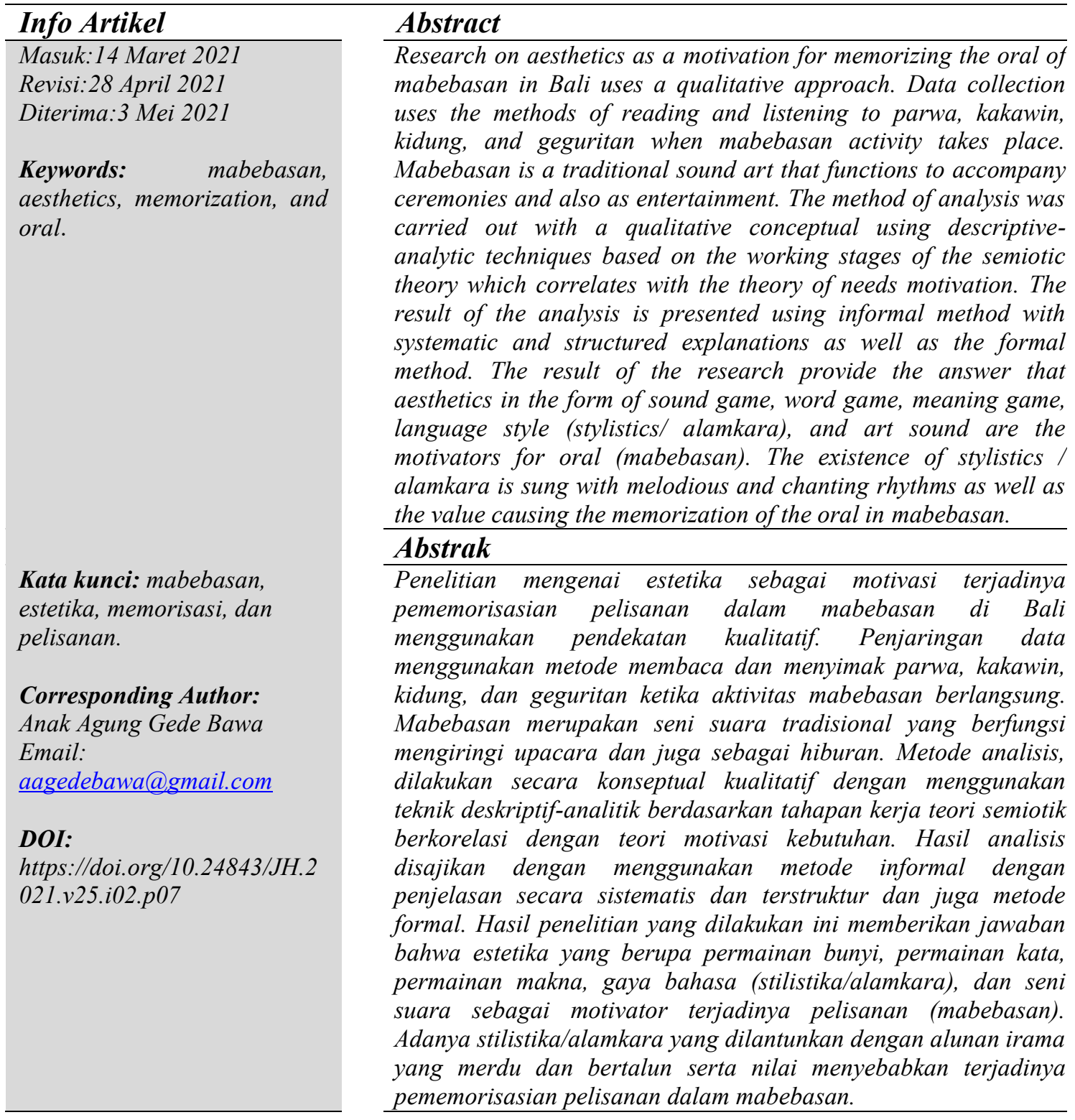

\section{PENDAHULUAN}

Karya sastra klasik terdokumentasi di Bali dalam berbagai bentuk, seperti bentuk Parwa, kakawin, kidung, sloka dan, geguritan. Hasil cipta tersebut sampai saat ini masih digemari dan mendapat tempat spesial di hati masyarakat Bali. Terlihat dari seringnya 
karya sastra tersebut dilantunkan secara merdu, di setiap aktivitas upacara keagamaan (agama Hindu) sebagai tanda adanya kegiatan olah sastra tradisional di Bali yang bersifat lisan. Olah sastra klasik Bali biasanya dilakukan oleh kelompok atau perkumpulan penggemar karya sastra klasik. Dalam kegiatan olah sastra tersebut ada yang menembangkan, menerjemahkan, dan kadang-kadang ada yang mengulasnya dan atau mengomentari. Aktivitas seperti itu di Bali disebut dengan istilah mabebasan atau mapepaosan (Medera, 1997: 24). Aktivitas itu dilakukan atas dasar kesadaran dan kesenangan dengan konsep ngayah menjadi landasannya. Ngayah di sini diartikan sebagai: 'pengabdian diri tanpa berharap imbalan' (Anom dkk. 2009:43). Bila dicermati konsep ngayah seperti ini dapat dikatakan betapa tingginya kesadaran para penggemar olah sastra klasik/ tradisional di Bali dan mulianya kegiatan ngayah yang dilakukan. Melalui ngayah berharap agar upacara yang berlangsung berhasil atau sukses, dan memperoleh kepuasan bagi pendengar atau penikmatnya termasuk para olah sastra itu sendiri

Aktivitas olah sastra mabebasan bisa disaksikan atau dipirsa pada acara televisi lokal yang ada di Bali, seperti Bali TV, TVRI Stasiun Denpasar dan Dewata TV. Begitu pula pada siaran-siaran radio lokal di Bali, seperti RRI maupun radio-radio swasta menyiarkannya. Aktivitas mabebasan juga sering dilakukan menggunakan sarana pesawat komunikasi seperti Hand Talky (HT) dan atau Hand Phone (HP). Kenyataan seperti itu menandakan bahwa olah sastra mabebasan sangat digemari oleh masyarakat Bali. Kegiatan olah sastra mabebasan mendapat tempat istimewa di hati masyarakat, karena olah sastra mengandung nilai-nilai seni yang adiluhung. Di sisi lain, objek yang digunakan dalam olah sastra mabebasan tersebut, berupa naskah yang teksnya memuat wacana-wacana atau cerita-cerita yang sarat akan petuah-petuah yang sangat berguna sebagai pedoman hidup; seperti Naskah Bhagawadghita, Sarasamus-chaya, Kakawin Ramâyana, Kakawin Bharatayuddha, Kakawin Sutasoma, Kakawin Nìti Sâstra, Kakawin Nirârtha Prakrēta, Kakawin Arjuna Wiwaha, Kakawin Smaradahana, Kakawin Bhomântaka merupakan contoh konkret yang sering dipakai sebagai materi mabebasan.

Sebagaimana yang telah diuraikan di atas, bahwa mabebasan merupakan cabang seni khususnya seni suara klasik, yang di dalamnya terkandung unsur sastra yang menggunakan bahasa sebagai media penyampainya. Sebagai cabang seni, tentu saja di dalam mabebasan terkandung unsur-unsur estetika atau keindahan. Tanpa keindahan tentu saja mabebasan akan kurang menarik sehingga kurang diminati oleh masyarakatnya. Keadaan seperti itu sangat menarik untuk diteliti. Penelitian yang mengungkap masalah mabebasan telah banyak dilakukan. Sukartha dkk (1995), membahas Peranan Mebebasan Dalam Menyebarluaskan Nilai-Nilai Budaya Tradisional Masyarakat Bali; I Wayan Jendra, (1996) berbicara mengenai Kedwibahasaan Bahasa Bali dan Bahasa Indonesia dalam Aktivitas Seni Mebebasan di Bali, membahas masalah seni mabebasan dan budaya Bali; Sukartha (2015) melanjutkan penelitiannya tentang mabebasan yang membahas mengenai Kelisanan Dalam Mabebasan Di Bali (desertasi) mengulas tentang hal-hal yang berbau lisan dalam mabebasan di Bali, juga menyinggung masalah motivasi pelisanan. Namun berbicara mengenai estetika yang memotivasi terjadinya pememorisasian pelisanan dalam mabebasan di Bali belum banyak dibicarakan. Fenomena seperti itulah yang menjadi alasan untuk mengangkatnya sebagai karya tulis. 


\section{METODE DAN TEORI}

Penelitian mengenai estetika yang memotivasi terjadinya pememorian pelisanan dalam mambebaan di Bali menggunkan pendekatan kualitatif. Pengumpulan data menggunakan metode membaca dan menyimak teks yang digunakan dalam aktivitas mabebasan naskah yang selalu ada adalah Kakawin Ramayana dan Arjuna Wiwaha. Data yang terkumpul dianalisis dengan menggunakan tode metode kualitatif konseptual dengan teknik deskriptifanalitik berdasarkan tahapan kerja teori strukturalisme semiotik.

Kakawin merupakan sebuah bentuk karya sastra. Sebagai sebuah karya sastra memiliki setruktur yang dibangun oleh keterkaitan hubungan antar unsurnya sebagai suatu kesatuan yang bulat dan utuh dan tidak bisa saling meniadakan (Teeuw, 1983; Endraswara, 2013). Teori semiotik digunakan, didalam karya sastra termuat system tanda yang bermakna bila dimaknai oleh pembaca berdasarkan konvensi yang berkaitan dengannya (Teeuw, 1988:5, Riffeterre, 1979:9). Berkorelasi dengan teori motivasi kebutuhan Abram Moslow, adanyanya kebutuhan akan sesuatu yang muncul dan didorong oleh kesadaran dalam diri (Haeper,1954) untuk membedah motivasi estetika pelisanannya. Sebagai fakta semiotik, karya sastra memiliki dua aspek, yaitu aspek empirik dan aspek nonempirik (Faruk, 2012). Demikian halnya, kakawin sebagai karya sastra dan sekaligus fakta semiotik dipandang memiliki aspek empirik dan aspek nonempirik. Teks kakawin disajikan melalui tulisan sebagai lambang bunyi yang bisa dilihat (dibaca) dan disimak merupakan sesuatu yang empirik. Sementara itu, aspek nonempirik kakawin adalah makna. Makna kakawin dipandang berada dalam kesadaran kolektif kesastraan dan kesadaran kolektif kebudayaan.

\section{HASIL DAN PEMBAHASAN}

\section{Estetika sebagai Motivasi Pelisanan dalam Mabebasan di Bali.}

\section{Estetika}

Estetika yang dimaksudkan Panuti Sudjiman (1984) sebagai telaah emosi dan pikiran dalam hubungannya dengan rasa keindahan dalam sastra. Estetika berurusan dengan konsep-konsep tentang keindahan. Sedangkan sastra diartikan karya, baik lisan maupun tertulis yang memiliki berbagai ciri keunggulan seperti keorisinalan, keartistikan, keindahan dalam isi dan ungkapannya. Estetika juga dapat diartikan sebagai:1) 'cabang filsafat yang menelaah dan membahas tentang seni dan keindahan serta tanggapan manusia terhadapnya'; 2) 'kepekaan terhadap seni dan keindahan' (Moeliono. 2014;382),

Berbicara mengenai keindahan, estetika tidak terbataskan pada masalah keindahan secara konkret (lahiriah) seperti pada karya-karya lukisan, patung dan lain-lain. Tetapi lebih dari itu ingin melihat apa yang tersembunyi di balik gejala tersebut. Sebagai contoh di dalam karya-karya sastra. Mutu sebuah karya sastra tidak dapat hanya dilihat dari aspek verbal melalui penggunaan bahasa yang indah-indah seperti dalam sistem persajakan atau pilihan kata, tetapi ia perlu dilihat secara menyeluruh misalnya dari aspek tema atau amanat serta aspek struktur pada tataran sistem sastra secara menyeluruh termasuk di dalamnya aspek nilai (value).

\section{Kaidah Estetik Karya Sastra}

Nilai estetik dalam karya sastra tradisi terutama jenis kakawin menurut Zoetmulder (1983) erat kaitannya dengan perbuatan yoga. Bahkan mengarang kakawin dapat dianggap sebagai suatu perbuatan yoga atau melakukan latihanlatihan rohani tertentu. Dalam konteks ini bagi seorang penyair kakawin (kawi) 
adalah semacam yoga sedangkan sang kawi sendiri adalah seorang yogi, yaitu orang yang melakukan latihan rohani tertentu. Dalam pandangan agama HinduJawa, konsep yoga mengacu pada usaha setiap orang untuk mencapai kesatuan dengan sang pencipta (dewata). Cara seperti ini setiap orang yang melakukannya akan dapat mencapai kelepasan, bebas dari rantai ikatan kehidupan.

Kakawin oleh pengawi juga merupakan sarana bagi terciptanya kaidah-kaidah estetika. Sarana yang dapat digunakan untuk mewujudkan Sang Dewa dan sekaligus sebagai objek pemusatan pikiran, baik bagi sang penciptanya maupun untuk orang yang membaca, mendengar dan, menyimak kakawin tersebut. Tercipta suatu karya kakawin serta menikmatinya, orang dapat larut di dalam pesona keindahan yang disebut langö. Kaidah-kaidah estetik seperti ini dalam karya jenis kakawin dinyatakan di dalam bait-bait pembuka (manggala).

Bagi seorang pujangga kakawin (kawi) menggubah karya kakawin dapat dikatakan sebagai petunjuk mengenai proses pembacaan serta pemahaman nilai-nilai budaya termasuk pemahaman pada kaidah-kaidah estetik. Demikian pula dengan membaca teks kakawin dapat dikatakan telah mengikuti serta mengulangi usaha sang kawi dalam rangka menyatukan pikiran dengan alam semesta (skala) ke alam niskala (tidak nyata) untuk mencapai kesatuan dengan dewa.

Sebagai misal dalam Kakawin Arjunawiwaha, dijumpai kaidah estetik yang berpusat pada yoga melalui seorang tokoh yang disebutnya sebagai "sang paramartha pandhita". Dalam cerita, tokoh dimaksud diujudkan sebagai kesatria utama Arjuna yang karena ketekunannya melakukan tapa (yoga) sehingga oleh Dewata Agung yoganya dianggap sudah sempurna. Dengan kesempurnaan tapanya, akhirnya Arjuna berhasil memperoleh apa yang disebutnya sebagai "pencerahan rohani" (jñana wisesa atau jñana siddhi) yang dapat membangkitkan kebahagiaan yang melebihi kenikmatan sanggama (sukaning samāgama). Demikian pula dengan sempurnanya tapa Arjuna akhirnya ia berhasil mencapai atau meperoleh anugrah Sang Dewa berupa senjata sakti sebagaimana yang menjadi misi utama tapanya. Adapun naskah kakawin yang digunakan sebagai objek dalam penelitian ini selain Kakawin Arjunawiwaha adalah Kakawin Ramayana, Kakawin Bhomāntaka, Kakawin Nêgara Kêrtagama, Kakawin Siwaratrikalpa, dan Kakawin Kansayana.

\section{Estetika Pemotivasi Pelisanan dakam Mabebasan}

Mabebasan merupakan cabang seni khususnya seni suara dan seni sastra. Sebagai cabang seni tentu saja estetika merupakan bagian yang tidak terpisahkan dari mabebasan. Nilai estetika sebagai seni presentasional, terutama dalam bidang sastra lebih menonjol dibandingkan dengan estetika yang ada dalam bidang nonsastra. Dalam bidang sastra, nilai estetik bisa ditemukan secara jelas melalui bahasa. Dalam bidang seni suara, nilai estetik dijumpai melalui permainan bunyi dan atau makna berupa nyanyian yang dilagukan dengan alunan suara yang merdu dan bertalun serta diartikan dengan bahasa yang mudah dimengerti (bahasa sasaran) dan kadangkadang disertai dengan tanggapan atau bahasan. Perpaduan ini melahirkan mabebasan sebagai cabang seni yang sangat estetik atau estetik yang bernilai tinggi.

Mabebasan sebagai cabang seni yang bernilai tinggi, yang menggunakan bahasa sebagai media pengantarnya, tentu saja akan saling mengkait dengan nilai etika. Bahkan, nilai etika sering lebih menonjol dibandingkan dengan nilai estetika. Alasannya karena nilai 
etika lebih mudah dideteksi dan dipahami dari pada nilai estetika. Perpaduan antara estetika dan etika yang terkandung dalam sastra lebih sering dibicarakan dibanding estetika yang ada di dalam nonsastra (Ratna,2007:204). Pembi- caraan mengenai estetika yang ada di dalam dunia sastra, tidak bisa dilepaskan dari bahasa yang mengisi lirik-lirik lagu tersebut. Lirik-lirik lagu yang menggunakan bahasa disebut estetik bila di dalamnya terkandung permainan bunyi, permainan kata, permainan makna, dan gaya bahasa. Gaya bahasa sebagai salah satu unsur keindahan atau estetika di dalam mabebasan mengandung unsur-unsur stilistika. Untuk memahaminya tentu saja diperlukan pemahaman tentang dasardasar stilistika sastra yang sangat beragam. Sebab, sastra memiliki keberbedaan dengan seni-seni lain seperti seni lukis, seni ukir, dan sejenisnya. Dalam sastra, bahasalah merupakan medium utama penyampai estetikanya.

Mabebasan yang tergolong ke dalam seni tradisional, mencakup kakawin, parwa, kidung dan geguritan memiliki ciri gaya atau stilistika tersendiri, yang mana estetika berupa permainan bunyi, kata, dan makna yang tersurat maupun tersirat dilagukan melalui olah vokal dengan suara yang merdu dan bertalun membuat pembaca, penikmat, serta partisipan terkesima. Melalui aktivitas tersbut, karya sastra tradisional mendapat sambutan dari masyarakat. Maka dari itu mabebasan menjadi digemari di Bali sampai saat ini. Kandungan nilai estetik dan etika merupakan faktor penyebabnya. Kemudian timbul pertanyaan, "dimana letak nilai estetiknya?”. Untuk menjawab pertanyaan itu diperlukan penjelasan mengenai stilistika yang ada dalam dunia puisi tradisional seperti kakawin, kidung, parwa dan geguritan yang digunakan dalam aktivitas mabebasan, sebagai seni sastra tradisional. Stilistika dalam mabebasan dikenal dengan nama alamkara.

\section{Stilistika/Alamkara}

Stilistika merupakan ilmu atau studi tentang stil ( style ). Dalam dunia sastra, style berarti 'suatu cara yang bersifat khusus atau khas, yang digunakan dalam mengungkap sesuatu'. Stilistika atau stil, disebut juga dengan istilah majas. Majas dalam dunia sastra kurang mendapat perhatian di bandingkan dengan stilistika. Majas tidak lain adalah kiasan, yang diambil dari kosa kata bahasa Yunani yaitu dari kata trope, dalam bahasa Inggris disamakan dengan figure of speech (Ratna, 2009:3). Pemakaian majas tertentu dapat mengubah atau menimbulkan nilai rasa atau konotasi tertentu. Majas (figurative language) adalah bahasa yang digunakan secara imajinatif, bukan dalam pengertian yang benar-benar secara alamiah saja. (Dale, 1971:162; Warriner, 1977:602). Dari uraian di atas, majas dapat diartikan sebagai bahasa kias atau figurative language, atau bahasa yang indah yang digunakan untuk menghaluskan atau meninggikan efek dengan cara memperkenalkan dan memperbandingkan suatu benda atau hal tertentu dengan benda lain atau hal lain yang lebih umum.

Di dalam karya puisi klasik seperti kakawin, kidung, dan geguritan istilahistilah di atas dapat disamakan dengan alamkara. Untuk itu, dalam kajian estetika di dalam mabebasan difokuskan pada alamkara.

Alamkara dalam dunia kakawin sudah sering dibicarakan. Hooykaas dalam "Stilistic Figures in Old Javanese Rāmāyana Kakawin" (1958b), termuat dalam JOI 7, ( Vol:3), pp 135-157, dan "Four Line Yamaka in the Old Javanese Rāmāyana" (1958a) yang termuat dalam JRAS, pp 122-138. Kemudian alamkara berturut-turut dibicarakan pula dalam tulisan Nengah Medera dalam "Canda 
Sebuah Analisis Metrum Kakawin Jawa Kuna" (1978), Nyoman Suarka dalam Telaah Sastra Kakawin (2009), dan I Nyoman Sukartha (2015) dalam disertasinya yang berjudul "Kelisanan Dalam Mabebasan Di Bali”.

Alamkara atau alangkara, alêngkara, langkara atau lêngkara diartikan sebagai: 'hiasan, dekorasi, hiasan-hiasan gaya, bahasa artistik, bahasa yang berbelit-belit ( terlalu dibuat-buat), sesuatu yang menakjubkan atau mempesona, dan bentuk yang fantastik (Hooykaas,1958:34). Lebih lanjut disampaikan alamkara dapat dibedakan menjadi dua yaitu: sabdhālamkara dan arthālamkara. Permainan bunyi bahasa di dalam kakawin disebut sabdhālamkara, sedangkan permainan arti atau makna kata di dalam kakawin disebut arthālamkara. Kandungan nilai estetik dalam alamkara ini merupakan salah satu faktor penyebab tertariknya orang untuk mempelajari kakawin dalam mabebasan. Alamkara dapat disamakan dengan majas (figure of speech). Di dalamnya terkandung nilai-nilai estetik yang sangat tinggi. Alamkara merupakan still atau stilistik yang khusus ada di dalam kakawin. Inilah secara tidak langsung mengakibatkan lestarinya seni mabebasan sampai saat ini. Adanya stilistika dalam wujud alamkara ini menarik minat orang untuk mempelajari dan bahkan menghafalkan ( meresitasi atau mememorisasi) bait-bait kakawin karena sangat indah untuk didengar, dinikmati melalui rasa dan pikiran. Terlebih lagi bila penembang kakawin memiliki suara merdu, sehingga menggelitik perasaan dan pikiran orang untuk belajar menembang, belajar menghafal dan belajar bahasanya termasuk memahami isinya. Singkatnya, alamkara sangat cocok dibicarakan dalam kesempatan ini dibandingkan dengan jenis estetika lain seperti majas dan sejenisnya. Di sisi lain, tentunya demi menghindari ketumpangtindihan uraian.

\section{Sabdhālamkara.}

Seperti telah dijelaskan di atas bahwa sabdhālamkara berarti permainan bunyi dalam kakawin. Permainan bunyi atau sabdhālamkara ini dibedakan menjadi dua yaitu: anuprasa dan yamaka (Hooykaas, 1958: 36).

\section{1) Anuprasa}

Anuprasa berarti permainan bunyi berupa asonansi (permainan bunyi vokal), dan aliterasi (permainan konsonan). Permainan bunyi yang berupa pengulangan vokal atau konsonan secara teratur sehingga menciptakan suatu gaya (stillistika) yang estetik. Anuprasa sangat banyak ditemukan di dalam kakawin, terutama dalam Kakawin Rāmāyana, Arjuna Wiwaha, Kangsāyana, Sutasoma, Naraka Wijaya dan masih banyak kakawin lainnya. Contoh wacana bait kakawin yang mengandung anuprasa dapat dilihat pada kutipan kakawin di bawah ini.

mwang Tandwān rangkêp patangkêp kiwa têngên apagut tandhang tinandhang, maprêp kaprêp silih prêp mamalu ya pinalu lyan manêmbung tinêmbung, Manggyat ginyat silih gyat pinupuh hana mupuh wira nampyal tinampyal, kapwa ng rangkal rinangkal pêkul ika mamêkul manandhêm pinandhêm. (Kakawin Kangsayana, XX:14)

Terjemahannya:

Lalu lengkap saling berhadapan, kirikanan berperang saling serang. Menyerang diseranga, saling serang saling pukul lain lagi saling tendang, Membentak dibentak, saling bentak, saking pukul, berani saling tampar.

sama pelintir, dipelintir, saling peluk dan saling lempar.

Dalam kutipan di atas, terdapat vokal $a, \hat{e}, u$ dan konsonan $k, l, m, r, p, n, t$ dan konsonan $y$, pada suku kata yang bergaris bawah di atas, diulang-ulang. 
Tujuannya tentu saja untuk memenuhi nilai estetika. Gaya estetik seperti ini banyak dijumpai di dalam kakawin.

Asonansi dan aliterasi ini membangun estetika yang bernilai tinggi seperti ini, banyak terdapat dalam kakawin. Hal ini merupakan salah satu penyebab orang senang mempelajari dan menghafalkan teks kakawin dalam aktivitas mabebasan. Lebih-lebih, bila bait-bait kakawin itu mempunyai keterkaitan dengan fungsi dan maknanya di dalam upacara adat keagamaan.

\section{2) Yamaka}

Yamaka merupakan permainan bunyi yang tersusun secara sistematis membentuk susunan berupa suku kata (silabel) atau kata (gabungan kata). Suku kata atau kata yang digunakan membangun keindahan/estetika dengan cara berulang-ulang. Adanya unsur pengulangan, Yamaka dapat disamakan dengan majas perulangan. Perulangan berupa silabel/suku kata atau kata, bisa ditempatkan pada awal baris, di tengah baris, di bagian akhir baris, bahkan bisa juga diulang pada awal baris bait berikutnya. Pengulangan silabel atau kata bisa memiliki makna yang sama (bersinonim), dan bisa juga mengandung makna yang berbeda. Pengulangan inilah yang membangun nilai estetik dalam bait-bait kakawin.

Yamaka dalam puisi India Bhatikâvya penggunaannya ditemukan sebanyak 20 jenis (Hooykaas, 1958:58). Namun dalam kakawin yamaka hanya ditemukan sebanyak 5 jenis. Kelima yamaka yang dimaksud adalah: (1) Kanci yamaka, (2) Puspa yamaka, (3) Padâdyanta yamaka, (4) Padanta yamaka dan, (5) Wrênta yamaka.

\section{(1) Kanci yamaka}

Kanci yamaka dimaksudkan adalah permainan bunyi yang berupa pengulangan suku kata atau kata yang terletak pada akhir baris sebelumnya, kemudian suku kata atau kata itu diulang pada awal baris berikutnya. Pengulangan juga bisa terjadi pada suku kata atau kata pada akhir baris bait sebelumnya diulang sebagai suku kata atau kata pertama baris pertama bait berikut dan setersnya.

Contoh

Wirūpaksāpaksākêmita ri dalêm ni ng pura wara, warah têka rowangnira ya masukātunggwa watangan, tangan-ti ngke tunggwa twawa sahana ning āyudha kabeh. kabeh ikang têka ta ya malaywan pinanahan (KRy 19,35).

Terjemahan:

Sang Wirupaksa berniat berjaga di dalam istana, perintahlah pasukannya agar masuk untuk menjaga tempat sidang, kamu semua jaga disini dan semua membawa senjata, semua musuh yang datang berlarian, dipanahlah.

Kata wara merupakan kata terakhir pada baris kesatu, diulang menjadi warah sebagai kata pertama pada baris kedua. Suku kata -tangan pada kata watangan merupakan suku kata terakhir baris kedua, diulang sebagai suku kata pertama pada baris ketiga menjadi tangan-ti. Kata kabeh yang merupakan kata terakhir baris ketiga diulang menjadi kata pertama pada baris keempat. Selanjutnya, suku kata nahan dalam kata pinanahan diulang pada baris kesatu bait berikutnya. Hal yang sama juga terjadi secara berlanjut pada: (KRy,19,36); (KRy,19:37); (KRy, 19:38). Lebih menariknya lagi kata terakhir dari bait (KRy 19,35), diulang menjadi kata awal baris pertama bait (KRy,19,36), begitu terjadi selanjutnya pada bait (KRy,19:37) dan (KRy, 19:38). Perhatikan kata atau suku kata yang bergaris bawah terjadi pengulangan yang disebut dengan istilah Kanci yamaka. Bentuk kanci yamaka seperti ini sangat disenangi oleh para pelaku mabebasan. Hal ini disebabkan oleh adanya pengulangan suku kata atau kata, yang 
akan memudahkan untuk mengingat atau menghafalkannya sebagai langkah memorisasi. Bait-bait kanci yamaka yang sangat populer dalam mabebasan yang digunakan sebagai pengiring upacara Manusa Yadnya dan Pitra Yadnya adalah wirama Wangsastha atau Swandewi yang bersumber pada Kakawain Rāmāyana (KRy,23:81- 86).

Contoh

Prihên têmên dharma dhumārana ng sarāt, $\quad$ Sarāga sang sādhu sireka tüt-tana, Tan a-rtha tan kāma pidonya tan yasia,

ya sa-kti sang sajjana dharma raksaka. (KRy, 23:81)

Terjemahan:

Utamakanlah kebenaran dalam mengayomi negara, kegemaran orang salehlah yang patut diteladani, bukan harta, bukan hawa nafsu dan bukan ketenaran yang ditujunya, keberhasilan orang bijak berpegang pada kebenaran hakiki.

Bait-bait kutipan di atas amat terkenal pada masyarakat pelaku mabebasan. Hampir setiap pelaku mabebasan hafal akan teks kakawin yang bersumber dari Kakawin Ramayana ini. Alasannya adalah, karena teks kakawin ini mengandung ajaran mulia yang bisa dijadikan bekal bagi mereka yang akan memimpin, dan juga dipercaya berguna untuk bekal menuju surga (moksa) bagi roh orang yang meninggal dunia.

\section{(2) Puspa Yamaka}

Puspa Yamaka adalah suatu permainan bunyi pada bangun puisi (kakawin), yang berupa pengulangan suku kata terakhir setiap barisnya dan memiliki vokal sama. Maksudnya adalah vokal pada suku kata (silabel) terakhir setiap baris dalam satu baitnya sama. Bentuk ini mirip dengan syair dalam sastra modern yang sajaknya $a, a, a, a$. Contoh

Makulilingan ring talaga kabeh-nya, dada mamupak pangkaja sahana- nya, sulur inalapnyâmêng-amênga do-nya, pada masêkar kesiara rinurunya. (KRy, 17:130)

Terjemahan

Semuanya mengelilingi pinggiran telaga, sama-sama memetik bunga teratai seadanya, tangkai bunga dipetiknya digunakan untuk bermainmain, memua pada berbunga benang sari yang telah jatuh.

Kutipan di atas dengan jelas memberikan gambaran mengenai permainan bunyi [a] yang terjadi pada suku kata terakhir [ nya ] setiap barisnya dalam satu bait. Hal yang sama juga terdapat pada pupuh 19 bait 122 (KRy. 19. 122) yaitu bunyi [u] pada suku kata [kung] setiap barisnya.

\section{(3)PadādyantaYamaka}

Padādyanta Yamaka adalah, permainan bunyi pada bangun kakawin yang berupa perulangan kata (bentuk ulang) pada awal baris setiap barisnya. Perulangan ini terlihat seperti bentuk ulang (dwipurwa). Untuk jelasnya dapat dilihat pada kutipan bait kakawin di bawah ini.

$\underline{\text { Tuhu-tuhu dewī wangsiaja manulus, }}$

Sari-sari tan len mānawa winuwus,

Duga-duga datā sādhu sira putus,

Tan alang-alang wadwa ri sira huwus. Terjemahan:

Betul-betul keturunan bangsawan sempurna,

Setiap saat hanya ajaran agama yang dibicarakan,

Jujur, pemurah, suci dan ahli

Bukan kepalang para pembantunya tunduk akan perintahnya.

Kutipan bait kakawin di atas menggambarkan adanya perulangan kata awal baris pada setiap barisnya. Perulangan kata yang dimaksud seperti: tuhu-tuhu, sari-sari, duga-duga dan, alang-alang. Jadi tampak seperti kata berulang. Di samping itu dalam bait terliat pula perulangan silabel/suku kata pada akhir baris. Suku kata yang diulang 
adalah suku kata [-us] pada akhir keempat barisnya.

\section{(4) Padanta Yamaka}

Padanta Yamaka adalah permainan bunyi pada bangun kakawin berupa perulangan kata (bentuk ulang) pada bagian akhir baris setiap barisnya. Bentuk permainan bunyi padanta yamaka yaitu perulangan pada akhir setiap barisnya dapat dilihat seperti kutipan berikut.

Wêruh sire naya nikāng inuli-ulih, sāri-sāri ning ujar iningêt-ingêt, buddhi pûrwaka huwus mang-angênangên, yar sahur kadi swara gêrêh matêrêh.

Terjemahan:

Beliau tahu rahasia yang dibicarakan, intisari yang dibicarakan diingatingat, yang menyebabkan orang sadar sudah dipikirkan, lalu berkata dengan teriakan bagai suara guruh.

\section{(5) Wrênta Yamaka}

Wrênta Yamaka adalah permainan bunyi pada bangun puisi (kakawin) yang berupa perulangan suku kata (silabel) atau kata pada awal baris setiap barisnya dalam satu bait kakawin. Permainan bunyi wrênta yamaka terlihat pada kutipan kakawin Rāmāyana seperti berikut ini.

Mandāra ramya sumêkar kadi sampun ahyas, manda-ng angin ta ya tumūb ya têbêng ta molah, manda-ng ulah juga kadi pwa masö manungsung, mandonining bramara mattakên ujarnya.

Terjemahan:

Gunung Mandara bagai berhias indah pohon yang sedang berbunga, angin berhembus perlahan tiada henti menyebabkan pohon bergerak, gerakannya pelan bagaikan datang menyongsong. suara lembut si kumbang mabuk bagai tegur sapanya.
Dalam bait kakawin di atas menggambarkan terjadinya permainan bunyi berupa perulangan suku kata [man] atau kata [manda] pada silabel atau kata awal setiap barisnya. Dengan kata lain dapat dikatakan bahwa keempat barisnya dimulai dengan silabel atau kata yang sama yaitu suku kata [man] dan kata [manda] dalam bait-bait kakawin disebut dengan istilah Wrênta Yamaka.

\section{Arthālamkara}

Arthālamkara adalah permainan makna/arti kata dalam kakawin. Permainan makna kata ini bertujuan untuk menambah daya estetik kakawin. Bentuk ini dapat disamakan dengan gaya bahasa ataupun majas dalam dunia semantik. Arthālamkara bisa dibedakan menjadi 16 jenis seperti: rupaka, rupakabhyadika, wyatireka, slesia, upareksa, wibhawana, atisayokti, warta, yatha sangkawa, wirodha, ninda stuti, nidarsana, wisosekti, arthāntarānyasa, upānyasa, ananwaya (Suarka,2012:3650). Berikut akan disampaikan sekilas mengenai jenis-jenis arthālamkara sebagai berikut.

\section{1) Rupaka}

Rupaka adalah permainan makna kata dengan menggunakan perbandingan. Rupaka dapat disamakan dengan majas perbandingan di dalam semantik. Kata-kata yang digunakan sebagai adanya ciri perbandingan seperti; kadi, lwir, tulya, akên, upama, kaharan, tuwi, padanya/padanira, atmaka/satmaka, dan pinaka.

Contoh:

$\underline{\text { Kadi }}$ megha manghudanakên (KRy, I.5.1).'Bagaikan mendung yang menyebabkan hujan'

Padanira yarwehakên ikang dana.(KRy,I.5.2). 'Persamaannya manakala memberi sedekah' 
Tuwi sira mitra hyang Indra bakti têmên (KRy,I.7.2). 'Betul-betul beliau sahabat dewa Indra sangat bakti'.

Kutipan di atas terlihat adanya unsur perbandingan dengan menyamakan atau memperbandingkan. Persamaan yang dimaksud seperti mengumpamakan Raja Dasaratha yang disamakan seperti mendung. Dasaratha diibaratkan sebagai mendung yang akan menurunkan hujan. Begitulah persamaannya ketika beliau memberikan sedekah kepada para fakir miskin, orang sengsara, orang buta, lebih-lebih lagi kepada orang suci (pendeta). Keberhasilan Dasarata mengayomi rakyatnya, itulah yang menyebabkan beliau dianggap sebagai sahabat Dewa Indra.

\section{2) Rupakabhyadika}

Rupakabhyadika adalah merupakan permainan makna atau arti kata berupa gaya bahasa pelambangan (simbolisme). Suatu objek digunakan sebagai simbol atau lambang untuk mewakili ungkapan hati atau perasaan.

Nyeki ng reka wacān uninya ya iko cihnany unêng ni nghulun (KRy,XI.22.2)

'Bacalah suratku ini, yang isinya sebagai cirri rasa rindu hamba'.

Nyā ng simsim pakirim narendra ya ikāsparsinta têka kahidêp (KRy,XI.22.4)

Adapun cincin yang tuanku kirim itu kuibaratkan pelukanmu'.

Kutipan kakawin di atas berbagai benda seperti: surat dan cincin digunakan sebagai simbol atau pelambangan. Surat disimbolkan sebagai wakil rasa rindu dan cincin dimaknai sebagai pelukan. Jadi objek yang dijadikan simbol berupa benda.

\section{3) Wyatireka}

Wyatireka adalah permainan makna kata dengan membesar-besarkan atau melebih-lebihkan sifat atau keadaan suatu objek yang dibicarakan. Gaya bahasa seperti ini dapat disamakan dengan majas hiperbola. Di bawah ini disampaikan beberapa contoh gaya bahasa wyatireka:

Sang suksmeng têlênging samādhi Siwa Buddha sira sakala niskalātmaka (KNkg,I.1.2)

'Engkau tersembunyi di dalam samadi, Siwa Budha Engkau, perwujudan nyata dan taknyata'

Gahan ri Lêngkā kadi kanting wulan (KRy,V.1. 2)

'Taklain di Lengka yang bagi sahabat bulan'.

Kutipan baris kakawin di atas, terdapat unkapan gaya bahasa melebihlebihkan atau meninggikan suatu objek (hiperbola). Tuhan dikatakan berwujud sangat rahasia (Siwa dan Budha), dan bersemayam di dalam samadi (keheningan). Istana Alengka dikatakan sahabat Bulan. Jadi ada unsur pengagungan yang berlebihan, walaupun kenyataannya objek itu tidak terlihat dan tidak terpikirkan, tetapi diyakini ada secara nyata.

\section{4) Slesa}

Slesa ialah permainan makna/gaya bahasa dalam kakawin, satu kata memiliki makna lebih dari satu (polisemi). Sebagai contoh gaya bahasa permainan makna (slesa) seperti di bawah ini.

“Rāgādi nusuh maparö"(KRy,I.4. 1)

'Nafsu dan lain-lain adalah musuh yang paling dekat'

Kutipan di atas menyatakan adanya permainan makna (slesa) yang tampak pada kata rāga yang bermakna warna, warna-warni (terutama warna merah), nafsu,cinta, tubuh/badan (Zoetmulder, 1995: 899).

\section{5) Upareksa}

Upareksa adalah permainan makna dengan menggunakan kata-kata yang mengandung makna yang berlawanan atau berbalasan (paradoks). Gaya bahasa upareksa sebagai contoh seperti disampaikan di bawah ini. 
"Tandwa rangkêp patangkêp kiwa têngên apagut ramya tandhang tinandhang”. (KRy,XX. 14. 1) 'Setelah lengkap berhadaphadapanlah barisannya, kiri-kanan bertempur dengan sengit, saling tendang-menendang'.

Bentuk upareksa terlihat pada kata rangkêp patangkêp, kiwa têngên, dan tandhang tinandhang karena maknanya bertentangan atau berlawanan.

\section{6) Wibhawana}

Wibhawana adalah merupakan permainan makna yang menyatakan keberadaan suatu objek, tanpa penyebab yang jelas. Teknik pengungkapan objek dengan gaya wibhawana, sering dijumpai dalam kakawin seperti berikut.

"Ri dalem ikang tataka hana teki rakwa Siwa lingga nora ginawe". (KSrk,V.5.3)

'Di dalam air itu konon ada lingga Dewa Siwa yang ada tanpa dibuat'.

Kutipan baris kakawin di atas diceritakan adanya patung Dewa Siwa (lingga). Lingga ini ada tanpa ada yang membuatnya. Jadi, dapat dikatakan bahwa lingga itu ada tanpa sebab.

\section{7) Atisayokti}

Atisayokti adalah merupakan permainan makna yang memban-dingkan suatu objek dengan objek lain yang tidak sebanding (majas hiperbola). Atisayokti dapat dilihat pada baris kakawin berikut.

"Kadi pwa kendran nikanang mahendra ya". (KRy, XI.57.1)

'Gunung Mahendra bagai kahyangan Dewa Indra'.

"Lawan manik yeka silā talanya ya”. (KRy, XI.57.3)

'Batu pipih ibarat batu permata'

Kutipan baris kakawin di atas mengandung pengandaian objek yang melebih-lebihkan (atisayokti) yaitu gunung Mahendra diumpamakan seperti keidahan istana Dewa Indra. Batu pipih diibaratkan seperti indahnya batu permata (istana Dewa Indra).

\section{8) Warta}

Warta adalah suatu permainan makna di dalam kakawin, dengan melukiskan seseorang sebagai objek yang disamakan dengan keadaan alam yang sesungguhnya.

Sebagai contoh warta dalam kakawin dapat dilihat pada kutipan berikut.

"Wêngi ya huwus daśa deśa pêtêng ya”. (KRy, XI. 79. 2)

Malam pun tiba, seluruh penjuru gelap gulita'.

"Umilu pêtêng ta manahnira ta denya”. (KRy, XI.79.4)

Ikut gelap gulitalah pikiran beliau olehnya'.

Pada kutipan di atas digambarkan gelapnya hari menjelang malam sama dengan gelapnya pikiran Rama yang sedang bersedih karena ditinggal oleh Sita. Di sini terdapat gaya bahasa yang sangat estetik. Keadaan alam disamakan dengan keadaan pikiran atau perasaan seseorang.

\section{9) Yatha Sangkawa}

Yatha Sangkawa adalah suatu permainan makna di dalam kakawin dengan ungkapan pelukisan suatu keadaan/peristiwa seperti: keadaan berbahaya, perang, saat genting atau kritis, keluh kesah penderitaan, bahkan keadaan sedang dimabuk asmara. Penggambaran yatha sangkawa adalah sebagai berikut.

\section{"Anghing mātya waneh angên-angên} niskārya tāku $n$ hana" (KRy, XI.24.2)

'Hanya matilah yang ada dalam benak angan-anganku, hidupku terasa sia-sia'

Kutipan baris kakawin di atas menggambarkan keadaan seseorang yang sedang dilanda kesedihan yang mendalam dan hidupnya terasa sia-sia, 
dipikirannya hanya ada kematian untuk mengahiri hidupnya.

\section{0) Wirodha}

Wirodha adalah suatu permainan makna yang melukiskan sesuatu objek dengan cara yang berlawanan. Dalam gaya bahasa wirodha terdapat suatu pengungkapan keadaan merendahkan diri sendiri. Wirodha banyak dijumpai di dalam kakawin. Sebagai contoh dapat dilihat pada kutipan berikut.

"Om sêmbah ning anātha tingghalana de triloka sarana” (KAw, X.1.1)

"Ya Tuhan terimalah sembah sujud si hina dina ini oleh-Mu yang menguasai jagat triloka ini'.

"Sang sāksāt mêtu yan hana wwang amutêr tutur pinahayu”. (KAw,X.1.4)

'Engkau akan menampakkan diri bila ada orang yang membicarakan filsafat kebenaran'.

Kutipan kakawin di atas terdapat gaya bahasa yang bermakna merendahkan diri (di Bali disebut dengan sikap Ngalap Kasor). Kata yang digunakan adalah anātha yang berarti 'sangat hina' atau 'hina dina'. Arjuna dikenal sebagai ksatria amat sakti, ditakuti, disegani, tampan mengatakan dirinya sangat hina. Pernyataan Arjuna itu merupakan pernyataan yang berlawanan dengan kenyataan Arjuna yang sebenarnya adalah orang yang sakti mandraguna. Jadi gaya bahasa wirodha terbukti ada di dalam kakawin yang merupakan gaya bahasa yang memotivasi pelisanan dalam mabebasan di Bali.

\section{1) Nindastūti.}

Nindastūti adalah permainan makna yang digunakan untuk mencela atau memuji suatu objek dengan ungkapan yang berlawanan. Sebagai contoh gaya bahasa nindastūti sebagai berikut.

Prabhu kita Rāwanātisaya sakti jayeng bhuwana, pranatha musuhta bhakti matakut sahananya kabeh, Surapati sanghyang Indra tuwi bhakti sira pranatha, kathamapi dūrnaya pwa kita hina tamat panulus (KRy,V.4)

Terjemahan:

Raja Rawana kamu, teramat sakti dan unggul di dunia, Sanagat tunduk semua musuhmu, bakti, takut kepadamu, Raja para dewa Hyang Indra betul-betul bakti dan sangat tunduk, tetapi kau ternyata bodoh, lemah tidak tulus benar.

Kutipan bait kakawin di atas, baris 1, 2, dan, 3 berisi sanjungan terhadap Rahwana. Namun, baris 4 Rahwana dicela dan sangat direndahkan. Ungkapan tersebut sebenarnya mengandung makna melecehkan kesaktian Rahwana tetapi dengan cara menyanjung (Suarka, 2009:46).

\section{2) Nidarsana.}

Nidarsana adalah merupakan permainan makna untuk melukiskan sesuatu objek yang benar-benar terjadi sesuai kenyataan, dengan cara membanding-bandingkan objek tersebut dengan benda-benda yang ada secara nyata. Sebagai contoh gaya bahasa Nidarsana sebagai berikut.

"Hana ya magöng kadi parwwata māwan", (KRy,XI.75.2). 'Ada yang besar sebesar Gunung Himawan'

"Pasilih-silih nikanang suka duka". (KRy, XI.75.3). 'Suka dan duka datang silih berganti'

Kutipan baris kakawin di atas, jelas terlihat adanya unsur pelukisan suatu abjek, yang benar-benar ada dalam dunia nyata dan dialami seseorang. Pelukisan suasana suka dan duka pasti dialami oleh seseorang dalam hidupnya datang silih berganti. Gaya bahasa nidarsana itu sangat menarik sehingga sangat disenangi oleh para pelaku mabebasan. Oleh karena itu tidak jarang para pelaku mabebasan ingin menghafalkannya. Maka tidak berlebihan bila dikatakan bahwa bentuk nidarsana merupakan motivator pelisanan dalam mabebasan. 


\section{3) Wisosekti}

Wisosekti adalah permaina makna yang melukisan sifat-sifat buruk atau jahat seseorang. Gaya bahasa atau permainan makna berupa wisosekti sebagai contoh dapat dilihat pada kutipan berikut.

Mighneng ayajña umati wiku tan padosa, Nā dharmaning asंura rāksasa janma jat̄̄, Murkāti sāhasa mamañcana bañcaneng rāt, Krura swabhāwa mami tan hana sādhu buddhi (KRy,II.39)

Terjemahan:

Mengganggu orang beryadnya (kurban) dan membunuh pendeta tanpa dosa,Itu merupakan pekerjaan raksasa dari lahir, selalu marah merencanakan bencana di dunia, kami berwatak ganas tidak punya rasa belas kasih.

Kutipan di atas menggambarkan sifat jelek manusia disamakan dengan sifat raksasa. Artinya, segala sifat-sifat yang jelek, jahat, dan suka membencanai orang adalah sifat raksasa. Dalam hal ini, terdapat hukum relativitas mengenai kebenaran. Benar menurut manusia belum tentu benar menurut raksasa. Begitu pula sebaliknya. Kebenaran raksasa tidaklah benar menurut hukum manusia, dan ajaran agama. Gaya bahasa wisosekti memang banyak terdapat di dalam kakawin. Namun, gaya bahasa ini kurang menarik sehingga kurang memotivasi orang untuk melisankan/ mememorisasikannya.

\section{4) Arthāntaranyasa}

Arthāntaranyasa adalah permainan makna melalui ungkapan yang berbeda untuk menyampaikan makna yang sama. Permainan makna seperti ini dapat dilihat pada kutipan berikut.

Mwang Rāhu yekana cinakra gulūnya denta, kweh detya dānawa anung talu denta nguni, prākkalpa dibya têmahan wāraha rūpa,
Sanghyang lêmah kalêbu nguni dinārananta (KRy, II.48)

Terjemahan.

Dan Sang Rahu itu dicakra Lehernya olehmu, Banyak raksasa dan danawa dibunuh olehmu dahulu, Jaman dahulu penjelmaanmu sangat mulya menjadi babi, Dahulu ketika dunia tenggelam kamu dilindungi.

Kutipan di atas memberikan gambaran bahwa beberapa kata yang berbeda, digunakan untuk menyatakan arti atau makna yang sama. Kata-kata yang dimaksud seperti: cinakra, prākkalpa, waraha dan, kalêbu yang mana keempat kata ini menyatakan arti atau makna yang sama yaitu Rama sebagai penjelmaan dari Dewa Wisnu.

Pemakaian gaya bahasa permainan makna untuk mengungkapkan makna yang sama dengan ungkapan yang berbeda banyak ditemukan di dalam karya sastra tradisional seperti: kakawin, palawakia, kidung dan geguritan. Kenyataan ini tidaklah berlebihan mengingat karya sastra tradisional kebanyakan memuat cerita yang bertemakan kebajikan yang selalu menang melawan kebatilan. Keadaan ini pulalah yang mendorong para pelaku mabebasan sering mengha- falkan atau mememorisasi/meresitasi bait-bait kakawin, palawakia, kidung maupun geguritan yang mengandung gaya bahasa Arthāntaranyasa. Keadaan ini mengandung makna bahwa gaya bahasa ini termasuk salah satu gaya bahasa yang memotivasi pelisanan dalam mabebasan.

\section{5) Upanyāsa}

Upanyāsa adalah suatu permainan makna yang memuat tentang anjurananjuran atau ajakan. Ajuran yang dimaksud adalah sejenis ajakan untuk melakukan sesuatu atau tidak melakukan sesuatu tindakan. Dalam kakawin kebanyakan anjuran yang diungkap berupa anjuran untuk berbuat kebajikan 
atau susila seperti terlihat pada kutipan berikut.

$$
\begin{aligned}
& \text { Anghing kita nāthangkwa ari, } \\
& \text { Mrastākna satrunta kabeh, } \\
& \text { Rāmādhama yekan pisani, } \\
& \text { mwang Lakșmana Sugrīwa pusus. } \\
& \text { (KRy,XXII:16) }
\end{aligned}
$$

Terjemahan:

Hanya engkau harapanku dinda, untuk memusnahkan musuh kita semua, bunuhlah sekalian si Rama yang bodoh, Serta si Laksmana, Sugriwa, hancurkan!.

Kakawin bait di atas, mengandung ajakan atau anjuran Raja Rahwana kepada adiknya si Kumbhakarna, untuk maju berperang melawan musuhnya yang menyerang kerajaan Alengka. Anjuran yang bermakna sama dengan perintah dalam bentuk halus sangat jelas terkandung dalam kutipan di atas. Ini berarti gaya bahasa upanyasa termasuk ungkapan yang memotivasi pelisanan dalam mabebasan.

\section{6) Anamaya}

Anamaya adalah permainan makna untuk menyampaikan perbandingan dengan mengandaikan suatu objek tanpa ada objek pembanding lain (zero). Permainan makna Anamaya dapat dilihat pada bait berikut.

Darppāng kidang ya makidangkidangan ya mādrês, Wetnyān saratsamaya kāla dumeh ya darppā, Ngkane têgal-têgal hawān mamangan-mangan ya, Sang Rama Lakșmana alah magirang tumon ya. (KRy,II:15)

Terjemahan.

Kidang binal berlompat-lompatan dengan cepat, musim semilah yang menyebabkan ia riang gembira, di sana di ladang-ladang dan jalan ia mencari makanan, Rama dan Laksmana sangat senang ia melihat.

Kutipan di atas memberikan suatu gambaran permainan makna ananwaya, yang mana objek yang diandaikan atau diperbandingkan berobjek zero. Dengan kata lain, tidak ada objek yang diperbandingkan. Si kidang yang kegirangan karena musim semi tiba, dengan binal melonpat ke sana-ke mari. Panorama seperti itu sangat menyenangkan perasaan sang Rama dan Laksmana.

Pada kutipan tersebut di atas dapat dikatakan bahwa ada unsur perbandingan dengan pengandaian, namun objek yang diperbandingkan tidak ada atau zero. Bentuk semacam ini juga sering memotivasi pelaku mabebasan untuk mememorisasi atau meresitasi teks kakawin, kidung dan juga geguritan.

Dengan kata lain dapat dikatakan bahwa unsur estetika seperti: permainan bunyi, permainan kata, permainan makna kata, dan gaya bahasa yang berbentuk nyanyian dilagukan dengan alunan suara yang merdu dan bertalun membuat terjadinya pelisanan dalam mabebasan.

\section{SIMPULAN}

Bedasarkan pemaparan tersebut di atas, yang memotivasi terjadinya pelisanan dalam mabebasan disebabkan karena adanya usur-unsur estetika bahasa (stelistika/alamkara) dan seni suara didalamnya.

Estetika bahasa, seni suara, dan nilai yang difungsikan sebagai pengiring upacara (pañca yajña 'lima jenis kegiatan upacara dalam Agama Hindu) dan hiburan (untuk diri sendiri dan atau orang lain/penikmat) yang memotivasi terjadinya pememorian pelisanan dalam mabebasan.

\section{DAFTAR PUSTAKA}

Aminudin. (1990). Semantik Pengantar Studi Tentang Makna. Bandung: Sinar Baru

Endraswara, Suwardi. (2013). Teori Kritik Sastra: prinsip, falsafah, dan penerapan.Yogyakarta: CAPS (Center for Academic Publishing Service). 
Faruk. (2012). Metode Penelitian Sastra. Yogyakarta: Pustaka Pelajar.

Hooykaas,C. (1958a). "Four-line Yamaka in the Old Javanece Rāmayana", JRAS 58 (71), pp. 122-138.

Hooykaas,C. (1958b). "Stylistic Figures in the Old Javanece Rāmayana Kakawin”, JOI 7 (3), pp. 135-157

Jendra,I Wayan. (1996). “Kedwibahasaan Bahasa Bali dan Bahasa Indonesia Dalam Aktivitas Seni Mabebasan Di Bali" (Disertasi). Yogyakarta: Universitas Gajah Mada.

Medera, I Nengah. (1989). "Tradisi Mabebasan Sebagai Media Pemahaman,

Penghayatan dan Pelestarian Nilai Budaya": Makalah seminar.

Moeliono, Anton. (2008). Kamus Besar Bahasa Indonesia. Jakarta. Departemen Pendidikan Nasional.

Poerbatjaraka, Prof. Dr. R.M.Ng. (2010). Rāmāyaṇa Djawa Kuha Teks dan Terjemahan.Jilis I Sargah I-XII dan Jilid II Sargah XIIXXVI.Jakarta: Perpustakaan Nasional RI.

Sudjiman, Panuti.(1990). Kamus Istilah Sastra. (Editor). Jakarta: Universitas Indonesia.

Ratna, I Nyoman Kuta. (2009). Paradigma Sosiologi Sastra. Yogyakarta: Pustaka Pelajar.

Riana, I Ketut. (2009). Kakawin Deśa Warnana Uthawi Nâgara Kṛtâgama Masa Keemasan
Majapahit. Jakarta; PT Kompas Media Nusantara

Reffaterre, Michael. (1979). Semiotics of Poetry. Bloomington and London: Indiana University Press.

Suarka, I Nyoman. (2009). Telaah Sastra Kakawin. Denpasar: Pustaka Larasan

Sukartha, I Nyoman.(1995)." Peranan Mabebasan Dalam Menyebarluaskan Nilai-Nilai Budaya Masyarakat Bali". Denpasar: Depdikbud

Sukartha, I Nyoman. (2015). "Kelisanan Dalam Mabebasan Di Bali" (Desertasi). Denpasar: Universitas Udayana.

Teeuw, A. (1983). Membaca Dan Menilai Sastra. Jakarta: Pt. Gramedia

Teeuw, A. (1988). Sastra Dan Ilmu Sastra Pengantar Teori Sastra. Jakarta: Pustaka Jaya

Teeuw, A.(1994). Indonesia Antara Kelisanan Dan Keberaksaraan. Jakarta: Pustaka Jaya

Zoutmulder, P.J. (1983). "Kalangwan Sastra Jawa Kuna Selayang Pandang". Jakarta: Penerbit Jambatan

Zoutmulder, P.J. (2006). "Kamus Bahasa Jawa Kuna-Indonesia". Jakarta : Jambatan. 